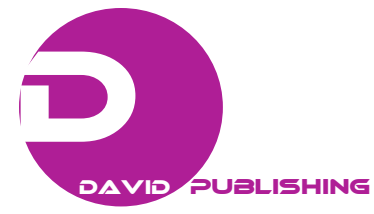

\title{
The Future Is Here: m-Learning in Higher Education
}

\author{
Charalampos Giousmpasoglou ${ }^{1}$ and Evangelia Marinakou ${ }^{2}$ \\ 1. Business School, Bahrain Polytechnic, Isa Town, Kingdom of Bahrain \\ 2. Faculty of Business \& Financial Sciences, Royal University for Women, Riffa, Kingdom of Bahrain
}

Received: June 10, 2013 / Accepted: June 20, 2013 / Published: June 25, 2013.

\begin{abstract}
The way we learn has changed dramatically in the new millennium. The introduction of e-learning in higher education in the late 1990s has opened Pandora's Box, and brought radical changes in the way where undergraduate and postgraduate programs are designed and delivered. The rapid developments and popularity of handheld devices such as smart phones and tablet PCs using wireless networks and mobile Internet have marked new developments in higher education, introducing the so-called mobile learning (m-learning). This means that university students can have access to their studies related content, anytime, anywhere in a personalized manner; this is what renders m-learning so popular and fashionable among university students globally. Nevertheless, instructors are now challenged as they have to adopt new pedagogies in learning and teaching. This paper discusses the concept of m-learning, as well as the current developments and challenges related to the major stakeholders (educators and students) in higher education.
\end{abstract}

Keywords: Higher education, m-learning, teaching/learning strategies.

\section{Introduction}

The rapid technological advancements in the context of globalization have changed our everyday lives in individual and societal level. Universities worldwide are among the first to embrace these changes and prepare their students with the appropriate tools to enter the "real" world of work. Two decades ago the technological advancements infiltrated the traditional classrooms with the introduction of e-learning. The extensive use of ICTs (information and communication technologies)-especially the use of the Internet-revolutionized and changed for good the design and delivery of curricula in universities around the world. During the last decade, an unseen "revolution" emerged from the introduction of m-learning tools in the classroom. The magnitude of these information technology developments is still not very well understood, simply because practice has run well ahead theory. In addition, it can be argued that the

Corresponding author: Charalampos Giousmpasoglou, Ph.D., research fields: hospitality management, HRM, managerial work, m-learning. E-mail: c.giousmpasoglou@polytechnic.bh. m-learning community is still fragmented among the various stakeholders, with different national perspectives, differences between academia and industry, and between the school, higher education and lifelong learning sectors [1]. Whether one looks at this phenomenon as a fad, threat, or a solution to educators' problems in delivering mainstream learning in higher education [2], it is currently a hot issue that needs our attention. This paper discusses the origins of m-learning, its pedagogical value and the current developments and challenges in higher education context; it is organized as follows: Section 2 discusses the origins and concepts of m-learning; Section 3 explores the opportunities and challenges from the use of m-learning in higher education; Section 4 presents results and discussions; Section 5 gives conclusions.

\section{The Origins and Concepts of $\mathbf{m}$-Learning}

In higher education context, the term mobile learning (m-learning) refers to the use of mobile and handheld devices, such as smart phones, laptops and tablet PCs, in the delivery of teaching and learning. Simply put, m-learning is defined as "the process of 